\title{
Communication And Research Skills In The Information Systems Curriculum: A Method Of Assessment
}

Paul J. Lazarony, California State University, Northridge, USA

Donna A. Driscoll, California State University, Northridge, USA

\begin{abstract}
Assessment of learning goals has become the norm in business programs in higher education across the country. This paper offers a methodology for the assessment of both communication skills and research skills within a curriculum of the Bachelor of Science in Information Systems Program. Program level learning goals assessed in this paper are: (1) To be able to effectively communicate complex information system and business concepts both orally and in writing, (2) To be able to do research of the IS literature that will allow life-long learning in the field, and (3) To understand both individual and group dynamics of project teams. The discussion of each of the three learning goals includes: (1) the assessment methodology, (2) the assessment results and (3) recommendations on how to close-the-loop.
\end{abstract}

Keywords: Information Systems, Assessment, Communication, Research

\section{INTRODUCTION}

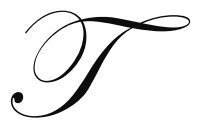

his paper examines the methodology used to assess communication and research skills in the information systems (IS) curriculum at California State University, Northridge (CSUN). Assessment of learning goals has rapidly become the norm in higher education business programs across the country. In the College of Business and Economics at CSUN, our assessment procedures must meet the assessment requirements of both the Association to Advance Collegiate Schools of Business (AACSB) and the Western Association of Schools and Colleges (WASC).

The three learning goals for the Bachelor of Science in Information Systems (BSIS) Program to be studied in this paper are:

1. To be able to effectively communicate complex information system and business concepts both orally and in writing,

2. To be able to do research of the IS literature that will allow life-long learning in the field, and

3. To understand both individual and group dynamics of project teams.

Students in the BSIS program are required to take IS 335 near the beginning of the Program and IS 451 near the end. Spring 2009 assignments and presentations from these two courses will be used in assessing these three learning goals.

\section{DESCRIPTION OF COURSES AND ASSIGNMENTS}

\section{IS 335--Information Technology for Business}

This is one of the first courses that the IS majors must take. In it, students learn about several different operating systems and about computer hardware. This class has a semester-long group project which requires a final 
written report and a final oral presentation. Students are asked to choose a new/cutting edge information technology as the topic to research for this assignment. During spring 2009, there were ten groups in this class. These ten group reports and ten group presentations will be used in this paper to explain the assessment methodology and results. The group report guidelines and presentation guidelines are in Appendix A.

\section{IS 451-- Systems Development Project}

This is one of the last courses that the IS majors must take. It deals with enterprise-wide systems and IT project management. This course also has a semester-long group project which requires a final written report and final oral presentation. Students are assigned a Fortune 500 company to research and then prepare an Enterprise Resource Planning Proposal for that company. During spring 2009, there were also ten groups in this class. These ten group reports and presentations will also be used in this paper to explain the assessment methodology and results. The group report guidelines are in Appendix B and the group presentation guidelines are in Appendix C.

\section{ASSESSMENT METHODOLOGY, RESULTS, AND RECOMMENDATIONS}

The assessment methodology, assessment results, and recommendations (closing the loop) will be presented in three sections: (1) Effective Oral Presentation Skills, (2) Effective Research of the IS Literature, and (3) Individual and Group Dynamics of Project Teams. Each of these three sections includes the three learning goals referenced in the introduction of this paper.

\section{(1) Effective Oral Presentation Skills}

BSIS graduates must have strong oral communication skills to be successful as an IS professional. In this section the following learning goal is being partially assessed: To be able to effectively communicate complex information system and business concepts orally and in writing.

\section{Methodology}

Both IS 335 and IS 451 have group oral presentations of their term projects. During the presentations, the instructor scored the groups on ten criteria (see tables 2 and 3). A score of 1 to 5 points was assigned for each of the criteria for a total of 50 possible points for each presentation team. To summarize the assessment data, the instructor used three assessment ranking categories: (1) Above Average, (2) Acceptable, and (3) Not Acceptable. Table 1 below shows how the points earned match up to the assessment ranking.

Table 1: Points Earned and Assessment Ranking

\begin{tabular}{|c|c|}
\hline Points Earned & Assessment Raking \\
\hline 4 to 5 & Above Average \\
\hline 2 to 3 & Acceptable \\
\hline Less than 2 & Not Acceptable \\
\hline
\end{tabular}

Results

Table 2 shows the assessment results for IS 335 and Table 3 shows the results for IS 451. By comparing the two tables, the reader will notice that not all of the assessment criteria "match up." Criteria B through F are grayed out in the table to de-emphasize those unmatched criteria.

Focusing on the matching criteria (A, G through $\mathrm{J}$ ) it seems clear that students later in the program perform better on their oral presentations than those just starting out. Student groups in both classes seem to have some problems with "getting the audience involved", where as both classes seem to do very well with the creation of the power point presentations (e.g. Electronic Visuals). 
IS students are required to do presentations in several IS classes taken between IS 335 and IS 451, which means they have much more practice in presenting by the time they reach IS 451 . This helps to explain these results.

\section{Recommendations (Closing the Loop)}

In future semesters, having a comprehensive set of matching criteria will aid in a more complete assessment of the presentation skills in both of these classes. Tips on getting the audience involved and emphasis on practice of the presentation will be a renewed focus in both classes as well.

Table 2: IS 335 Oral Presentation Assessment Results

\begin{tabular}{|c|c|c|c|c|}
\hline & Criteria & Not Acceptable & Acceptable & Above Average \\
\hline A & Presenters get the audience involved. & $20 \%$ & $50 \%$ & $30 \%$ \\
\hline $\mathrm{B}$ & Topic has been thoroughly researched. & $0 \%$ & $60 \%$ & $40 \%$ \\
\hline $\mathrm{C}$ & Content goes sufficiently beyond IS 335 material. & $0 \%$ & $60 \%$ & $40 \%$ \\
\hline $\mathrm{D}$ & Content is presented in a logical and organized manner. & $10 \%$ & $60 \%$ & $30 \%$ \\
\hline $\mathrm{E}$ & Material covered at junior level course or above. & $0 \%$ & $60 \%$ & $40 \%$ \\
\hline $\mathrm{F}$ & $\begin{array}{l}\text { Presenters speak to the audience directly and read little } \\
\text { from notes and slides. }\end{array}$ & $20 \%$ & $50 \%$ & $30 \%$ \\
\hline $\mathrm{G}$ & Electronic Visuals are created and used properly. & $0 \%$ & $40 \%$ & $60 \%$ \\
\hline $\mathrm{H}$ & $\begin{array}{l}\text { Each group member must speak an equal amount of } \\
\text { time. }\end{array}$ & $10 \%$ & $60 \%$ & $30 \%$ \\
\hline I & Presentation is rehearsed and runs smoothly. & $20 \%$ & $50 \%$ & $30 \%$ \\
\hline $\mathrm{J}$ & Presentation is within the $20 \mathrm{~min}$ time limit. & $10 \%$ & $20 \%$ & $70 \%$ \\
\hline
\end{tabular}

Note: This table shows the $\%$ of student groups which were found to be not acceptable, acceptable, and above average for each criteria.

Table 3: IS 451 Oral Presentation Assessment Results

\begin{tabular}{|l|l|c|c|c|}
\hline & \multicolumn{1}{|c|}{ Criteria } & Not Acceptable & Acceptable & Above Average \\
\hline A & $\begin{array}{l}\text { Introduce all group members and get the audience } \\
\text { involved. }\end{array}$ & $20 \%$ & $40 \%$ \\
\hline B & Preview the main points. & $0 \%$ & $40 \%$ & $60 \%$ \\
\hline C & Develop two to four main points from your project. & $0 \%$ & $40 \%$ & $60 \%$ \\
\hline D & Arrange points logically & $0 \%$ & $40 \%$ & $60 \%$ \\
\hline E & Have good transitions between the major points. & $20 \%$ & $50 \%$ & $30 \%$ \\
\hline F & Review the main points and provide a final focus. & $20 \%$ & $40 \%$ & $40 \%$ \\
\hline G & Electronic Visuals are created and used properly. & $0 \%$ & $20 \%$ & $80 \%$ \\
\hline H & $\begin{array}{l}\text { Each group member must speak an equal amount of } \\
\text { time. }\end{array}$ & $0 \%$ & $40 \%$ & $60 \%$ \\
\hline I & Presentation is rehearsed and runs smoothly. & $10 \%$ & $30 \%$ & $60 \%$ \\
\hline J & Presentation is within the 15 min time limit. & $0 \%$ & $20 \%$ & $80 \%$ \\
\hline
\end{tabular}

Note: This table shows the $\%$ of student groups which were found to be not acceptable, acceptable, and above average for each criteria.

\section{(2) Effective Research of the IS Literature}

Since IS involves the use of cutting edge technology, it is crucial that our IS graduates know how to research the IS literature so they can stay current in the field. In this section the following learning goal is being assessed: To be able to do research of the IS literature that will allow life-long learning in the field.

\section{Methodology}

As mentioned earlier, both IS 335 and IS 451 have semester long group projects. Both of these projects require the students to research the IS literature and to prepare their final reports in APA style. 
The instructor scored the groups on seven criteria (see tables 5 and 6). A score of 1 to 5 points was assigned for each of the criteria for a total of 35 possible points for each project team. To summarize the assessment data, the instructor again used three assessment ranking categories: 1) Above Average, 2) Acceptable, and 3) Not Acceptable. Table 4 below shows how the points earned match up to the assessment ranking.

Table 4: Points Earned and Assessment Ranking

\begin{tabular}{|c|c|}
\hline Points Earned & Assessment Raking \\
\hline 4 to 5 & Above Average \\
\hline 2 to 3 & Acceptable \\
\hline Less than 2 & Not Acceptable \\
\hline
\end{tabular}

Results

Table 5 shows the assessment results for IS 335 and Table 6 shows the results for IS 451 . Similar to the previous section, student groups in IS 451 seem to be somewhat better at researching the IS literature and formatting their reports in APA style than those in IS 335. It seems that some groups in both classes are still having some problems with criteria A, B and E, which all have to do with APA format. All groups, in both classes, seem to be able to meet the rest of the report requirements.

Recommendations (Closing the Loop)

An APA Style Guide is reviewed with the students in both classes. Perhaps having an APA referencing homework assignment, prior to the final project, will help to improve the students' ability to master the use of APA style in their reports.

Table 5: IS 335 Research Report APA Style Requirements

\begin{tabular}{|l|l|c|c|c|}
\hline & \multicolumn{1}{|c|}{ Criteria } & Not Acceptable & Acceptable & Above Average \\
\hline A & References in proper APA style format on reference page & $30 \%$ & $60 \%$ & $10 \%$ \\
\hline B & $\begin{array}{l}\text { In-text citations in proper APA style format throughout } \\
\text { document }\end{array}$ & $30 \%$ & $60 \%$ & $10 \%$ \\
\hline C & At least five different IS and business references & $0 \%$ & $90 \%$ & $10 \%$ \\
\hline D & At least five in-text citations & $0 \%$ & $90 \%$ & $10 \%$ \\
\hline E & Report Text is in APA style & $30 \%$ & $60 \%$ & $10 \%$ \\
\hline F & Report Tables are in APA style & $0 \%$ & $80 \%$ & $20 \%$ \\
\hline G & Six to eight pages in length & $0 \%$ & $90 \%$ & $10 \%$ \\
\hline
\end{tabular}

Note: This table shows the \% of student groups which were found to be not acceptable, acceptable, and above average for each criteria.

Table 6: IS 451 Research Report APA Style Requirements

\begin{tabular}{|l|l|c|c|c|}
\hline & \multicolumn{1}{|c|}{ Criteria } & Not Acceptable & Acceptable & Above Average \\
\hline A & References in proper APA style format on reference page & $10 \%$ & $60 \%$ & $40 \%$ \\
\hline B & $\begin{array}{l}\text { In-text citations in proper APA style format throughout } \\
\text { document }\end{array}$ & $10 \%$ & $50 \%$ & $40 \%$ \\
\hline C & At least fifteen different IS and business references & $0 \%$ & $60 \%$ & $40 \%$ \\
\hline D & At least fifteen in-text citations & $0 \%$ & $60 \%$ & $40 \%$ \\
\hline E & Report Text is in APA style & $10 \%$ & $50 \%$ & $40 \%$ \\
\hline F & Report Tables are in APA style & $0 \%$ & $60 \%$ & $40 \%$ \\
\hline G & At least 70 pages in length & $0 \%$ & $80 \%$ & $20 \%$ \\
\hline
\end{tabular}

Note: This table shows the \% of student groups which were found to be not acceptable, acceptable, and above average for each criteria. 


\section{(3) Individual and Group Dynamics of Project Teams}

IS professionals will do most of their work within a project team, so it is important that our graduates have strong teamwork skills In this section the following learning goal is being assessed: To understand both individual and group dynamics of project teams.

\section{Methodology}

As mentioned earlier, both IS 335 and IS 451 have semester long group projects which include a final report and oral presentation. At the beginning of the semester, a peer evaluation form is presented in both classes (see Appendix D). The criteria and ranking system is explained to the students and they are told this evaluation form is a required part of the final project. The evaluations are due after the final reports and presentations are completed.

Although students used a ranking of 1 to 4 to rate each team member's performance, these student ratings have been converted to the same assessment scale used in the previous sections of this report. Table 7 shows this conversion.

Table 7: Average Student Ranking and Assessment Ranking

\begin{tabular}{|c|c|}
\hline Average Student Ranking by Group & Assessment Raking \\
\hline 3 to 4 & Above Average \\
\hline 2 to 3 & Acceptable \\
\hline Less than 2 & Not Acceptable \\
\hline
\end{tabular}

Results

Table 8 shows the assessment results for IS 335 and Table 9 shows the results for IS 451.

Similar to the previous two sections, student groups in IS 451 seem to do much better at teamwork than those in IS 335. None of the groups in IS 451 ranked any of their group members in the Not Acceptable range. If groups worked exceptionally well together, they gave each group member rankings of 4 for all criteria. In IS 335, three groups (or 30\%) were in this above average category, where as in IS 451 five groups (or 50\%) were rated as aboveaverage.

\section{Recommendations (Closing the Loop)}

The instructor is very pleased with the assessment results in this section and the goal will be to maintain student performance at this level. It is not surprising that students are performing a little better in teams at the end of their program. Not only are they required to do teamwork in each IS course, they are also taught specifically how to work in teams in BUS 302 (the Gateway Course), which is a prerequisite for all 400 level IS classes. Moreover, the IS students are a very close-knit group, get to be very good friends, and therefore work very well together by the time they reach the end of the program.

Table 8: IS 335 Group Project Team Evaluation Results

\begin{tabular}{|l|l|c|c|c|}
\hline & \multicolumn{1}{|c|}{ Criteria } & Not Acceptable & Acceptable & Above Average \\
\hline A & Attended all group meetings or met all deadlines. & $10 \%$ & $50 \%$ & $40 \%$ \\
\hline B & Delivered results as promised or better. & $10 \%$ & $50 \%$ & $40 \%$ \\
\hline C & Contributed positively to the discussion. & $0 \%$ & $70 \%$ & $30 \%$ \\
\hline D & $\begin{array}{l}\text { Helped the group to improve the quality of this project } \\
\text { and to get it ready on time. }\end{array}$ & $0 \%$ & $70 \%$ \\
\hline E & $\begin{array}{l}\text { Has integrity and could be counted on to support the } \\
\text { group. }\end{array}$ & $10 \%$ & $60 \%$ & $30 \%$ \\
\hline F & Was energetic, enthusiastic and able to inspire others. & $0 \%$ & $70 \%$ & $30 \%$ \\
\hline F & Showed respect for others' feelings, opinions, and values & $0 \%$ & $50 \%$ & $50 \%$ \\
\hline
\end{tabular}

Note: This table shows the $\%$ of groups which were found to be not acceptable, acceptable, and above average for each of the criteria. 
Table 9: IS 451 Group Project Team Evaluation Results

\begin{tabular}{|l|l|c|c|c|}
\hline & \multicolumn{1}{|c|}{ Criteria } & Not Acceptable & Acceptable & Above Average \\
\hline A & Attended all group meetings or met all deadlines. & $0 \%$ & $40 \%$ & $60 \%$ \\
\hline B & Delivered results as promised or better. & $0 \%$ & $40 \%$ & $60 \%$ \\
\hline C & Contributed positively to the discussion. & $0 \%$ & $30 \%$ & $70 \%$ \\
\hline D & $\begin{array}{l}\text { Helped the group to improve the quality of this project } \\
\text { and to get it ready on time. }\end{array}$ & $0 \%$ & $30 \%$ \\
\hline E & $\begin{array}{l}\text { Has integrity and could be counted on to support the } \\
\text { group. }\end{array}$ & $0 \%$ & $40 \%$ & $60 \%$ \\
\hline F & Was energetic, enthusiastic and able to inspire others. & $0 \%$ & $50 \%$ & $50 \%$ \\
\hline G & Showed respect for others' feelings, opinions, and values & $0 \%$ & $40 \%$ & $60 \%$ \\
\hline
\end{tabular}

Note: This table shows the $\%$ of groups which were found to be not acceptable, acceptable, and above average for each of the criteria.

\section{CONCLUSIONS}

The stated purpose of this paper was to present the methodology for the assessment of both communication and research skills in an BSIS curriculum. After presenting the methodology, results and recommendations for each of the three learning goals, the following conclusions can be drawn:

1. It is helpful to have two courses, one at the beginning of the program and one at the end of the program, for the assessment comparison.

2. Existing course assignments (projects and presentations) can easily be used for the collection of the assessment data.

3. Scoring on assignments can be quickly converted to the three assessment categories: (1) Above Average, (2) Acceptable, and (3) Not Acceptable.

4. Closing-the-loop is an essential part of the assessment process. Course improvements can be easily determined from these assessment results.

\section{AUTHOR INFORMATION}

Dr. Paul J. Lazarony is an Associate Professor of Information Systems at California State University, Northridge. His current research interests are assessment, database, enterprise-wide systems, and IT project management. He received his $\mathrm{PhD}$ in Computer Technology and Business Education from the Ohio State University.

Dr. Donna A. Driscoll is a Professor of Information Systems at California State University, Northridge. Her current research interests are database, information assurance, and web-based systems development. She received her $\mathrm{PhD}$ in Business Administration (Accounting and Research Statistics) from the University of Southern California.

\section{REFERENCES}

1. Association for the Advancement of Collegiate Schools of Business. (2009). Accreditation Standards. Retrieved October 30, 2009, from www.aacsb.edu/accreditation.

2. Guffy, M.E. (2008). Business Communication: Process and Product, Sixth Edition. South-Western Cengage Learning, Boston, MA.

3. Meyers, M. (2007). A+ Certification All In One Exam Guide, Sixth Edition, McGraw Hill, San Francisco, CA.

4. Monk, E. and Wagner, B. (2009). Concepts in Enterprise Resource Planning, Third Edition. Course Technology Cengage Learning, Boston, MA.

5. Schwalbe, K. (2010). Information Technology Project Management, Sixth Edition. Course Technology Cengage Learning, Boston, MA.

6. Western Association of Schools and Colleges. (2009). Accrediting Commission for Senior College and Universities. Retrieved October 30, 2009, from www.wascsenior.org. 


\section{APPENDIX A: IS 335 GROUP PROJECT GUIDELINES}

Your team (3-4 members) can choose any IT product that is not covered (or is lightly covered) in your textbook. Cutting-edge and emerging IT is welcomed. You will write a report and create a presentation on this product and its company. Presentations are scheduled on the last two days of class and the report is due at the time of the presentation. You will present in order by group number. The report is worth 100 points and the presentation is worth 50 points.

Your group must choose a topic by week seven of the semester. Your professor must approve your topic so that duplicate presentations are avoided. Therefore, topics are approved on a first come, first served basis. You can email your potential topics to your professor, and you will receive a response letting you know if that topic is still available.

Report Requirements:

$\checkmark$ Cover page with the title and group member's full names.

$\checkmark$ Body of the report should be 10 to 15 pages double spaced with a 12 point font.

$\checkmark$ At least 8 in-text citations in APA Style (see the APA Style guide for format).

$\checkmark$ At least 8 references in APA Style (see the APA Style guide for format).

Report Outline:

A. Executive Summary

B. Company Analysis

1. Company History/Background Information

2. SWOT (Strengths, Weaknesses, Opportunities, Threats) Analysis: (e.g. Analysis of Cessna Aircraft Corporation)

3. Financial Analysis of the Company

i. Using the financial ratios, explain the financial health of the company. You may use information from the company's balance sheet and income statement, but do not insert

C. IT Product Functions and Features these entire statements into the report.

Presentation Requirements:

$\checkmark$ Each team will have 15 minutes to give their presentations.

$\checkmark$ Each group member must speak an equal amount of time.

$\checkmark$ Each team member must be in attendance the entire class time.

$\checkmark \quad$ Use electronic visuals (i.e. PowerPoint) and create handouts for each class member (42).

$\checkmark$ Do something to get the audience involved.

$\checkmark$ Practice your presentation so that it runs smoothly.

$\checkmark$ Speak to the audience, do not read your presentation.

$\checkmark$ Have fun with your presentation. This is your chance to show off your hard work to your classmates!

Presentation Outline:

A. Open with an Introduction and get the audience involved.

B. Choose two to four points from your report to present in the body of the presentation.

C. Close with a conclusion and provide a final focus.

Recommendations for getting the audience involved:

$\checkmark$ Ask questions throughout (or at the end of the presentation) and award prizes to those students who get them right.

$\checkmark \quad$ Have small prizes for your classmates.

$\checkmark$ Open your presentation with a question to the audience.

$\checkmark \quad$ Use a video or image to gain the audience's attention.

Each team member will have the opportunity to peer evaluate the other team members. Peer Evaluation forms are due no later than the final exam. 


\section{APPENDIX B}

\section{IS 451: Systems Development Project Outline}

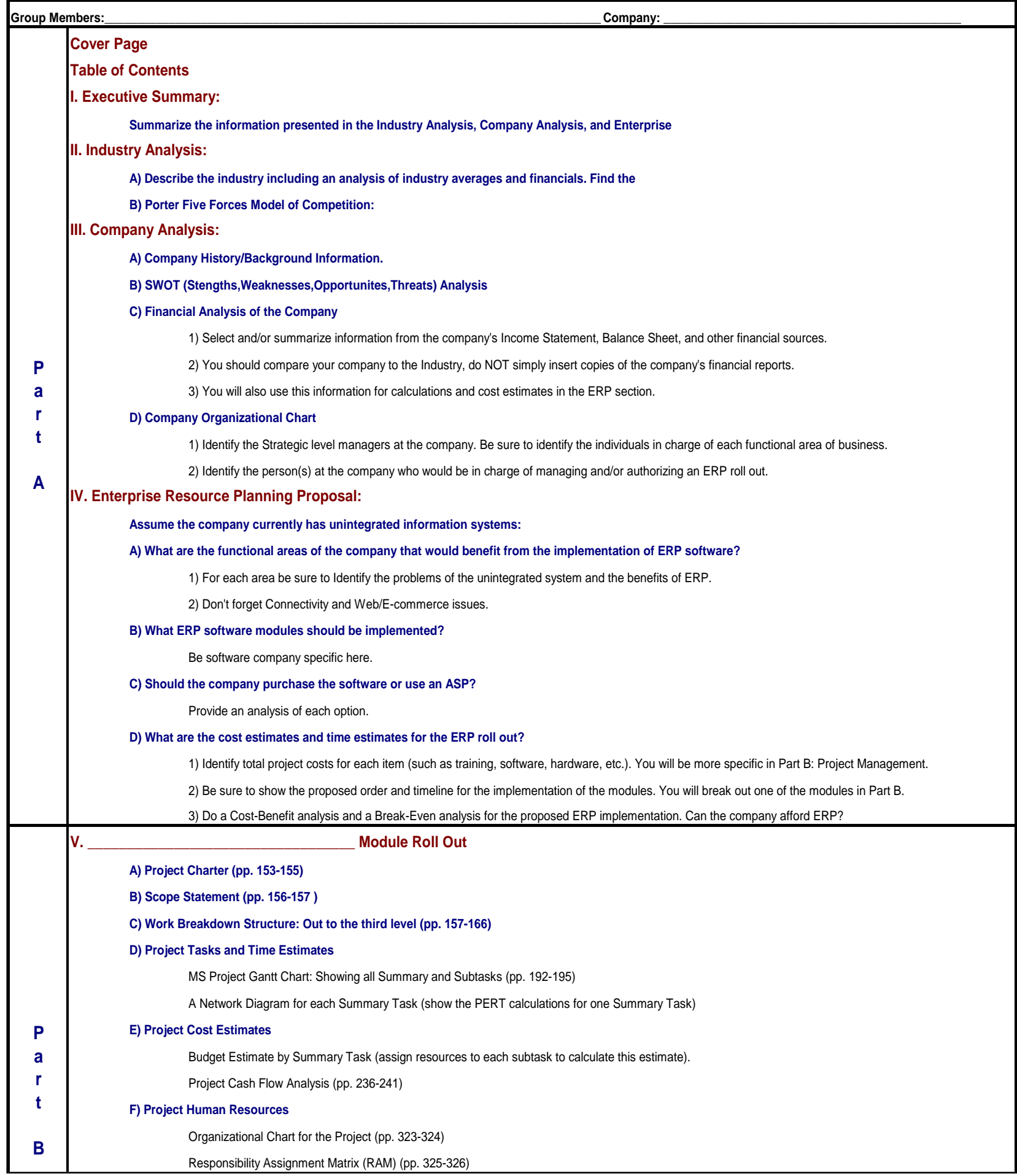




\section{APPENDIX C: IS 451: SYSTEMS DEVELOPMENT PROJECT}

\section{Group Presentation Guidelines}

Create a presentation based on your group project using the guidelines listed below. Project presentations are scheduled for the last day of class. You are expected to be in class for the entire period. Failure to attend this class session will adversely affect your overall project grade. This presentation is worth $5 \%$ of your overall course grade.

\section{I) Introduction:}

- Introduce all group members and get the audience involved.

- Preview the main points.

\section{II) Body:}

- Develop two to four main points from your project.

- Arrange the points logically.

- Have good transitions between the major points.

\section{III) Conclusion:}

- Review the main points and provide a final focus.

\section{Other Presentation Requirements:}

- Dress in professional business attire.

- Use electronic visuals for the presentation (i.e. PowerPoint) and create handouts for each class member.

- Have ALL group members talk.

- Practice your presentation so that it runs between 10 and 15 minutes. 


\section{APPENDIX D: GROUP PROJECT}

\section{Peer Evaluation Form}

Please evaluate the amount and quality of contribution made by each member of your group in the completion of your group project. You must sign your name at the bottom of this page for your response to count.

Your Name (print):

Do NOT grade yourself. Please write each group member's name and rate the extent to which the person displayed or did the following things. Rate all items according to the following scale:

\begin{tabular}{|c|l|l|l|l|l|}
\hline $\mathbf{0}$ & \multicolumn{1}{|c|}{$\mathbf{1}$} & $\mathbf{2}$ & $\mathbf{3}$ & \multicolumn{1}{|c|}{$\mathbf{4}$} & \multicolumn{1}{|c|}{ NA } \\
\hline Not at all & $\begin{array}{l}\text { To a small } \\
\text { extent }\end{array}$ & To some extent & To a large extent & $\begin{array}{l}\text { To a very large } \\
\text { extent }\end{array}$ & $\begin{array}{l}\text { Unable to } \\
\text { answer }\end{array}$ \\
\hline
\end{tabular}

List Full Names of Other Group Members

\begin{tabular}{|l|l|l|l|}
\hline \multicolumn{1}{|c|}{ Performance Measures } & \multicolumn{2}{c|}{ List Full Names of Other Group Members } \\
\hline $\begin{array}{l}\text { Attended all group meetings or } \\
\text { met all Deadlines }\end{array}$ & & & \\
\hline $\begin{array}{l}\text { Delivered results as promised or } \\
\text { better }\end{array}$ & & & \\
\hline $\begin{array}{l}\text { Contributed positively to the } \\
\text { discussion }\end{array}$ & & & \\
\hline $\begin{array}{l}\text { Helped the group to improve the } \\
\text { quality of this project and to get it } \\
\text { ready on time }\end{array}$ & & & \\
\hline $\begin{array}{l}\text { Has integrity and could be counted } \\
\text { on to support the group }\end{array}$ & & & \\
\hline $\begin{array}{l}\text { Was energetic, enthusiastic and } \\
\text { able to inspire others }\end{array}$ & & & \\
\hline $\begin{array}{l}\text { Showed respect for others' } \\
\text { feelings, opinions, and values }\end{array}$ & & & \\
\hline
\end{tabular}

Comments/Explanations: (Continue on the back of this page if necessary)

\section{Your Signature:}

Your evaluations will be used to calculate each member's project grade according to the following distribution:

$4=$ Equal to the group's grade

$3=10$ percent less than the team's grade

$2=20$ percent less than the team's grade

$1=30$ percent less than the team's grade

$0=$ No points since they did not contribute at all 